\title{
Analysis of Regional Development and The Needs of Clean Water Services in Medan City
}

\author{
Feby Milanie*, Sukaria Sinulingga, Sumono, Rujiman \\ Universitas Sumatera Utara, Indonesia \\ *feby.melanie.ok@gmail.com
}

\begin{abstract}
This study aims to analyze the influence of biophysical, economic, location, socio-cultural, institutional and environmental aspects on the water supply and the need for clean water in Medan city. Clean water was originally consideredas social goods that were freely accessed. The need for clean water for the population in Medan city is heightened due to the population growth, the increase on economic activities such as industrial growth in small-scale, medium and large industries, the development of public facilities and the increasing welfare of the community. The primary and secondary data obtained from relevant agencies and public in Medan city are used in this study. The secondary data were obtained starting in 1990 - 2012, while primary data were obtained from 30 respondents. The analysis model used is the structural equation models. The results have shown that; (i) biophysical, economic, location, sociocultural, institutional, environmental aspects positively influence the water supply and the need for clean water; (ii) there is a greater influence of water needs on the water supply, as compared to the effect of water supply to the needs of clean water.
\end{abstract}

Keywords: Regional development, water supply, water needs and structural equation models

\section{Introduction}

In line with the social, economic and cultural development, Medan city has grown to become one of the metropolitan cities in Indonesia and become the center of growth in the province of North Sumatra. The progress of Medan city is inseparable from the demands of the global competition, implementation of the regional autonomy and democracy. The global competition demands involvement in an environment that is conducive to improve the productivity and creativity and it has an appeal on strong competitiveness. The potential as a center of the regional economy is reflected on its location that functions strategically as the main gateway in the western region of Indonesia for the trading of goods and financial services on domestic, regional and international levels. The development and physical improvement of Medan city is directed to the construction of industrial estates and trade in order to improve the quality of life and encourage the development of business. All these desires are supported by several factors, among others; (i) $60.8 \%$ of the banking industry have chosen its respective locations in Medan city; (ii) $84.8 \%$ of bank credit are absorbed by the economic activities in the city; (iii) industrial business continues to grow, which has reached 5,596 businesses consisting of small, medium and large-scale enterprises; (iv) the availability of industrial areas; ( $v$ ) the development of shopping centers, shops, offices, new towns, hospitality etc; and (vi) the economic structure of the city is formed to be fundamentally stronger (Medan in Figures, 2011).

In the development of Medan city, there are five most prominent actors, namely; (i) government; (ii) private (business); (iii) community; (iv) professional; and (v) intellectual. All of them play a significant role in economic activities. The contribution of each sector especially the private sector has reached up to $80 \%$ of the total investment, while the government contributes by $20 \%$. One crucial policy pursued by the Government of Medan is to provide greater opportunities for the private sector and community to be involved not merely in activities that are profit-oriented, but also on overall urban development (Spatial Plan of Medan, Year 2011-2031). Meanwhile, the challenges that need to be faced include providing a range of facilities to the public, one of which lies in how to provide the needs for water to accommodate the economic activities with the increased number and density of the population. The needs for water from year to year are increasing due to the population and increased quality of life as well as the rapid growth of urban activities. The clean water is previously considered as the social goods that are accessed freely but now requires necessary economical costs. Along with the population growth and increased economic activities such as industrial growth, the development of public facilities increases the welfare of the community, thus the needs of the clean water in Medan city are increasing as well. 
The need for clean water in Medan city is still below the population's expectation, whereby it has problem in water supply distribution as well as the fact that the stock is limited to fulfill the needs by the population. The present condition of water services only provides $68 \%$ of the needs of fresh water needs for the population in 2012. To resolve this matter, the government in the city planned has come up with a thorough planning. In achieving the target on the services and quality of water services, it needs a dynamic planning which may change accordingly, aligned with the increase of the population due to births and urbanization, and the level of customer satisfaction that intentionally or unintentionally has to be improved. Therefore, the government should concern about these conditions of several factors internally and externally, while focusing on planning and executing comprehensively. Moreover, the problems occur with the private companies when the demand for clean water continously increases in quantity and quality, thus leaving an impact to the regional development. Again, it needs to formulate an alternative model of water management services. Based on the description that has been explained above, there is a growing demand for clean water that is not met, and thus the purposes of the study are established as follows:

- To analyze the factors that mostly have positive and significant effect on the regional development aspect concerning the need for clean water in Medan city.

- To analyze factors that mostly have positive and significant effect on the regional development aspect, with regards to the wáter supply in Medan city.

- To study about the provision of wáter that has a positive effect on wáter demand.

- To study about the needs for water that have a positive effect on water supply.

\section{Literature Review}

Regional Development: The regional development theory generally emphasizes on the process of improving the activity of a region or a region of empowerment. Development is defined not as 'doing something that was not there, but doing something that is already there but the quality and quantity needs to be improved or expanded'. So, the terms of regional development imply working onan area that is already developed which has potential or capacity but with the regional capacity needs to be improved. This regional development consists of various types of activities, both in government and the public sector that should be organized in order to attempt at improving the level of welfare. Meanwhile, a region is a geographic unit that forms a unified unit. Hanafiah (1982) formulated the following definition of the region as 'a region with a specific location and in certain aspects are different from other regions'. In a scientific context, a region is a unit of area where the entity of a particular space is used for the need to conduct a regional analysis (Setiono, 2011). The regional development is associated with the notion of development itself. The development can be defined as activities performed by a region or country to develop the quality of its people (Ernan, 2011). Thus, the development must be seen as a process that is interwoven and which interplays between the factors that leads to the development; it is a process that can be identified and analyzed carefully, so that the sequence of events that arises will be known. It seeks to realize an increase in the welfare of the society from one stage of development to other stages. This development is basically regarded as a process of change that is arranged in a deliberate and planned manner, to achieve one of the situations of a joint planning process.

The regional development in the long term is more emphasized on the introduction of natural resources and development of the potential of local areas that can generate economic growth and social well-being, including poverty alleviation, as well as the fact that it is considered as the efforts to overcome the existing development in the region in order to achieve its goals. In regard to the national development plan, the development of the region gives more emphasis to the preparation of an integrated regional development package to identify strategic potential sectors that need to be developed (Friedmann \& Allonso, 1964). Walter Isard, is a pioneer of science who examines the causal relationship of the regional development factors behind the creation of spatial factors namely; physical, social, economic and cultural factors. Moreover, Myrdal (1960) did mention about the theories that explain a relationship between the developed with the developing regions using the terms of backwash and spread effect. Meanwhile, Friedmann \& Allonso (1964) emphasized on the establishment of a hierarchy or level of development in order to facilitate the development of the system that became known as the center of the new growth theory. This means that the development of the region needs to develop new growth centers which are inter-related with the growth of the existing centers within the region. Douglass (2001) introduces a model of rural-urban linkages in a developing region aimed to create a mutually beneficial relationship between the villages and city or a win-win solution that is a generative relationship, rather than a parasite relationship. According to Budiharsono (2005), the development of coastal and marine regions using an 
integrated regional development approach at least pays attention to six aspects as the pillars of the regional development as illustrated in Figure 1. below:

Figure 1: The 6 Pillars of Regional Development

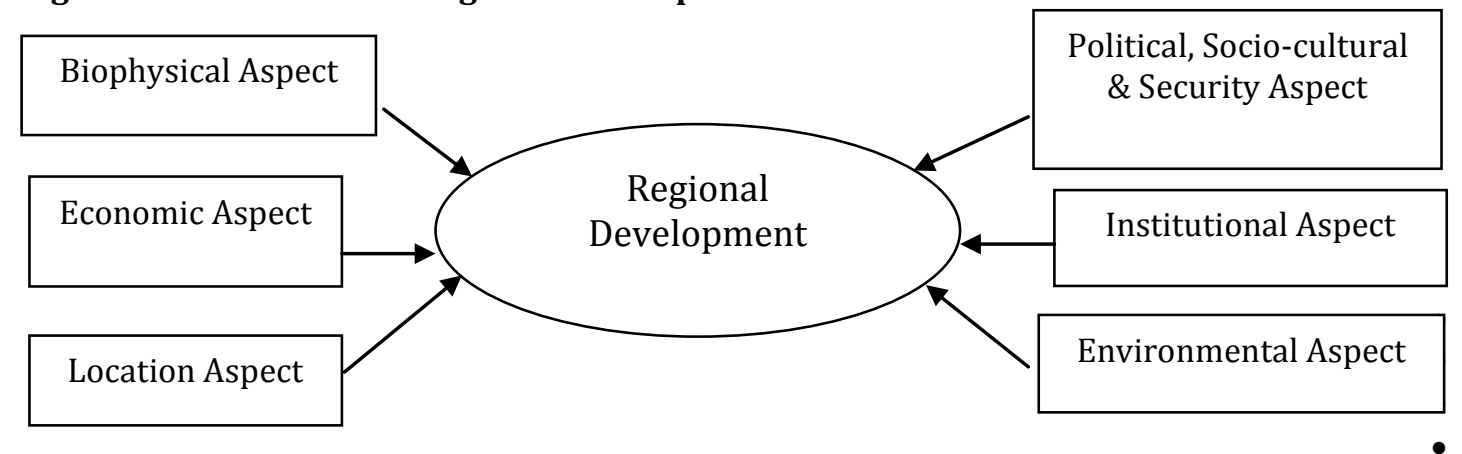

- The biophysical aspect includes the content of biological resources, non-biological resources, marine services, facilities and infrastructure that exist in the land, coast and sea.

- The economic aspect includes economic activities that occur in the coastal areas and oceans such as price, revenue and society's income.

- The location aspect includes space related to marine commodities which are produced, also it revolves in how to acquire the production facilities, processed and marketed. This aspect also shows the attractiveness of the location among the regions in terms of the production, processing and marketing.

- Political, socio-cultural and security aspects include the population, the quality of human resources, bargaining power (in politics), the culture of coastal communities as well as security (defence).

- The institutional aspect includes the institutions that exist in the management of coastal and ocean zones in a series of national and regional regulations. This enable positive responses to the economic development of coastal and marine regions.

- The environmental aspect includes the study of how the process of taking inputs from the ecosystem may cause negative externalities on the environment.

Factors of Water Sources Supply: There are five sources of water that can be used to cater for the needs of urban activities (Nace, 1976) namely:

- The rain water, which is the result of the condensation of water vapor that falls to the ground.

- Groundwater, water that flows from springs, artesian wells or taken through artificial wells

- Surface water, i.e. water rivers or lakes

- Desalination of sea water, or brackish ground water/salt

- The output of waste water treatment.

All the five sources of water, ground and surface water are used as the main choice of water sources due to the fact that these two sources are readily available, that they have a large number and are relatively better in terms of quality and also, they are qualified to be used as clean water.

\section{Conceptual Framework and Hypothesis}

Conceptual Framework: Based on the above description on the influences of clean water on the development in Medan city in terms of its impact on the population growth, growth of the population density, per capita income growth, economic growth, growth in the course of educational institutions, health personnel growth, industrial growth, growth of trade, growth in power and transport sector and the provision of the needs of clean water as well as the formulation of an alternative model of water management services to improve the needs of customers in Medan, thus the framework of this research is as follows:

Hypothesis: The hypotheses based on ideas and concepts described previously are as follows:

H1: There is a positive and significant effect on factors of regional development aspects towards the need for clean water in Medan city. 
H2: There is a positive and significant effect on factors of regional development aspects towards the provision of clean water in Medan city.

H3: There is a positive and significant effect on the provision of clean water towards the need for clean water in Medan city.

H4: There is a positive and significant effect on the need for clean water towards the supply of clean water in Medan city.

Figure 2: Conceptal Framework

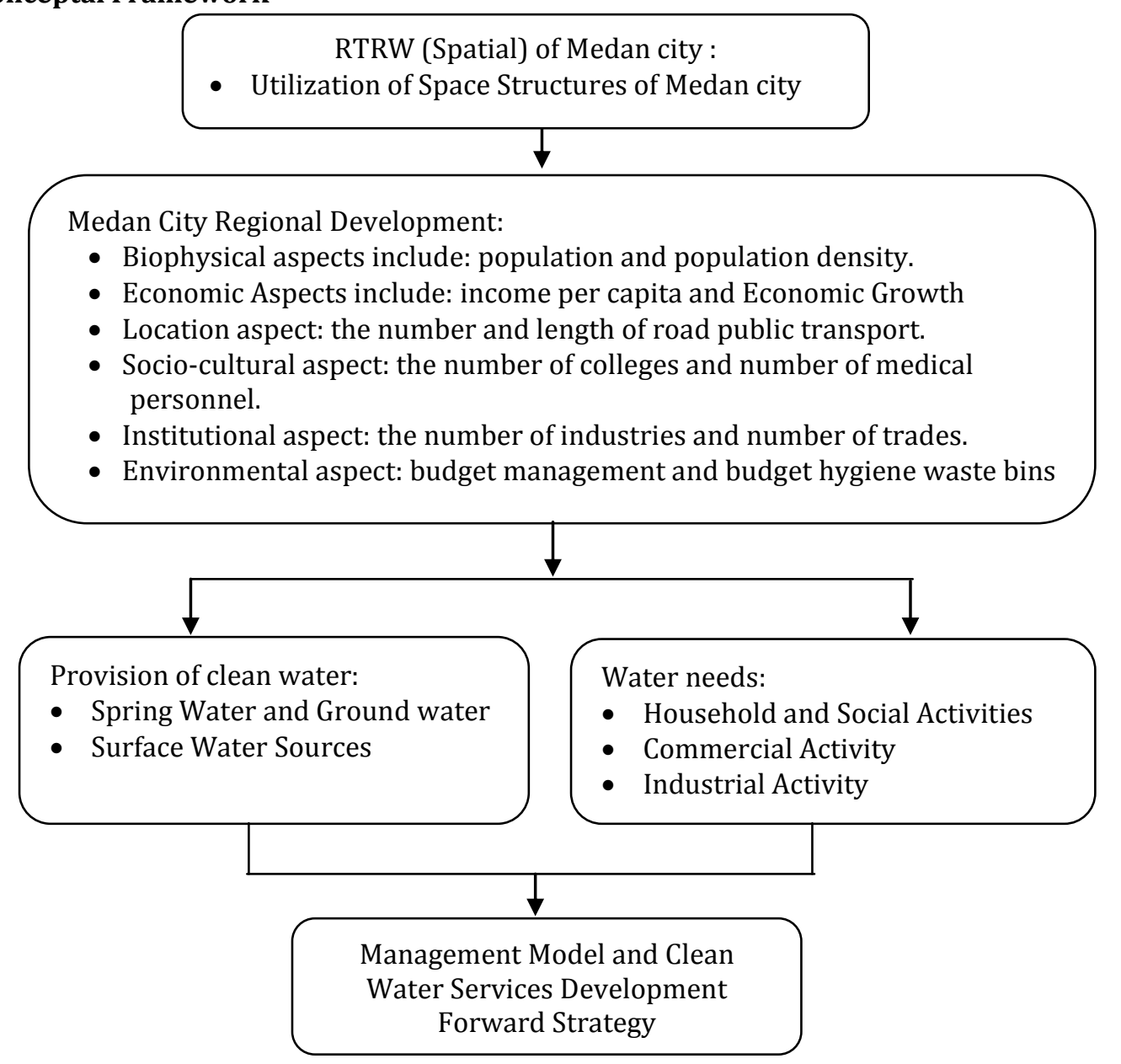

\section{Methodology}

Research Population: The study consists of the population from 21 sub-regions in Medan city which are divided into 5 main regions namely; North of Medan, South of Medan, West of Medan, East of Medan and Center of Medan. All of these represent the Medan city.

Data Collection and Analysis Methods: The data used in this study consist of secondary and primary data. The secondary data were obtained from the department or related agencies as well as from the literature of relevant studies. The range of years was from 1993 to 2013 . Meanwhile, the primary data were gathered from 30 respondents. The data were analyzed by measuring the Partial Least Square (PLS). The study consists of the variables of exogenous and endogenous latents. The construct indicators of the exogenous variables are the development of regions, where each of them was built by several indicators namely; the population, population density, per capita income, economic growth, the amount of freight, road length, number of institutional courses, number of medical personnel, number of industries, number of trade, budget of waste treatment and garbage cleaning. The specification of the model is presented in Figure 3. 
Figure 3: The Specification of the Model

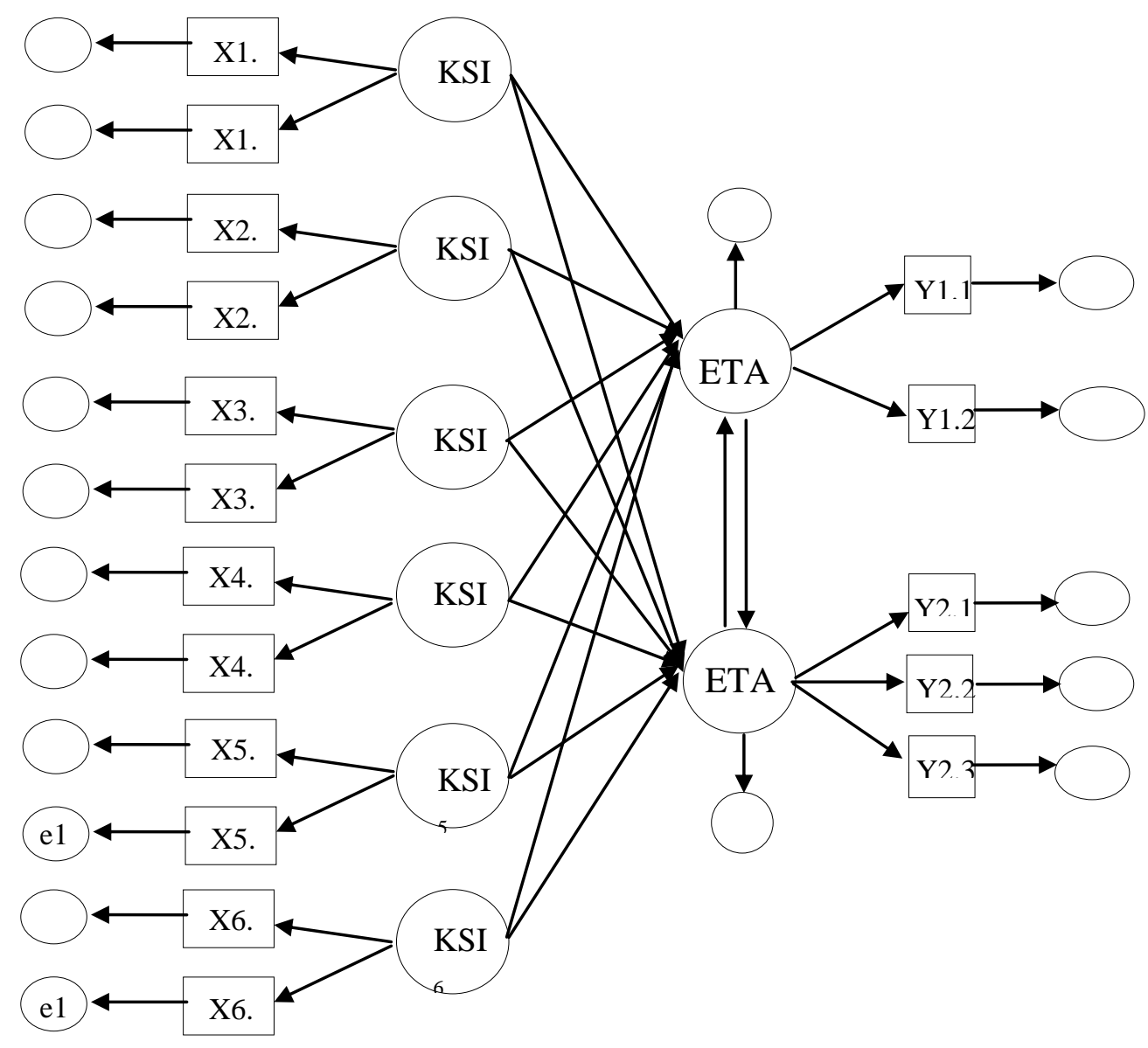

where:

KSI1 (X1) = latent exogenous variable of biophysical aspects; KSI3 (X3) = latent exogenous variable of location aspect; KSI4 (X4) = latent exogenous variable of socio-cultural aspect; KSI5 (X5) = latent exogenous variable of institutional aspect; KSI6 (X6) = latent exogenous variable of environmental aspect; ETA1 $(\mathrm{Y} 1)$ = latent endogenous variable of water supply; ETA2(Y2) = latent endogenous variable of water needs; X1.1 = indicator of population; X1.2 = indicator of population density; X2.1 = indicator of per capita income; X2.2 = indicator of economic growth; X3.1 = indicator number of transport; X3.2 = inidicator of path of length; X4.1 = indicator of number of colleges; X4.2 = indicator of medical personnel; X5.1 = indicator of number of industry; X5.2 = indicator of number of trade; X6.1 = indicator of waste treatment budget; X6.2 = indicator of garbage cleanliness budget; e1 ... E12 = The error term indicators of regional development; Y1.1 = indicator of ground water sources and springs; Y1.2 = indicator of surface water sources; e13... E14 = error term indicator of water supply; Y2.1 = indicator of social activities and household; Y2.2 = indicator of commercial activity; Y2.3 = indicator of industrial activity; e15... E17 = error term indicator of water needs. The model equations are the basic equations of the outer model that can be written as follows:

Table 1: Structural Equation for the Exogenous Latent Variable

\begin{tabular}{lll}
\hline Exogenous Latent Variable & Indicator & Equation Measures \\
\hline Biophysical Aspect $\left(\mathrm{KSI}_{1}\right.$ or $\left.\mathrm{X}_{1}\right)$ & $\mathrm{X}_{1.1} \& \mathrm{X}_{1.2}$ & $\mathrm{X}_{1.1}=\lambda_{\times 1.1} \mathrm{KSI}_{1}+\delta_{1.1} \& \mathrm{X}_{1.2}=\lambda_{\times 1.2} \mathrm{KSI}_{1}+\delta_{1.2}$ \\
Economic Aspect $\left(\mathrm{KSI}_{2}\right.$ or $\left.\mathrm{X}_{2}\right)$ & $\mathrm{X}_{2.1} \& \mathrm{X}_{2.2}$ & $\mathrm{X}_{2.1}=\lambda_{\times 2.1} \mathrm{KSI}_{2}+\delta_{2.1} \& \mathrm{X}_{2.2}=\lambda_{\times 2.2} \mathrm{KSI}_{2}+\delta_{2.1}$ \\
Location Aspect $\left(\mathrm{KSI}_{3}\right.$ or $\left.\mathrm{X}_{3}\right)$ & $\mathrm{X}_{3.1} \& \mathrm{X}_{3.2}$ & $\mathrm{X}_{3.1}=\lambda_{\times 3.1} \mathrm{KSI}_{3}+\delta_{2.1} \& \mathrm{X}_{3.2}=\lambda_{\times 3.2} \mathrm{KSI}_{3}+\delta_{2.1}$ \\
Socio-Cultural Aspect $\left(\mathrm{KSI}_{4}\right.$ or $\left.\mathrm{X}_{4}\right)$ & $\mathrm{X}_{4.1} \& \mathrm{X}_{4.2}$ & $\mathrm{X}_{4.1}=\lambda_{x 4.1} \mathrm{KSI}_{4}+\delta_{4.1} \& \mathrm{X}_{4.2}=\lambda_{\times 4.2} \mathrm{KSI}_{4}+\delta_{4.1}$ \\
Institutional Aspect $\left(\mathrm{KSI}_{5}\right.$ or $\left.\mathrm{X}_{5}\right)$ & $\mathrm{X}_{5.1} \& \mathrm{X}_{5.2}$ & $\mathrm{X}_{5.1}=\lambda_{\times 5.1} \mathrm{KSI}_{5}+\delta_{5.1} \& \mathrm{X}_{5.2}=\lambda_{\times 5.2} \mathrm{KSI}_{5}+\delta_{5.1}$ \\
Enviromental Aspect $\left(\mathrm{KSI}_{6}\right.$ or $\left.\mathrm{X}_{6}\right)$ & $\mathrm{X}_{6.1} \& \mathrm{X}_{6.2}$ & $\mathrm{X}_{6.1}=\lambda_{\times 6.1} \mathrm{KSI}_{6}+\delta_{6.1} \& \mathrm{X}_{6.2}=\lambda_{\times 6.2} \mathrm{KSI}_{6}+\delta_{6.1}$ \\
\hline
\end{tabular}


Table 2: Structural Equation for the Endogenous Latent Variable

\begin{tabular}{ll}
\hline Endogenous Latent Variable & Equation Model \\
\hline Water Supply $\left(\mathrm{ETA}_{1}\right.$ or $\left.\mathrm{Y}_{1}\right)$ & $\mathrm{ETA}_{1}=\lambda_{\mathrm{x} 1} \mathrm{KSI}_{1}+\lambda_{\mathrm{x} 2} \mathrm{KSI}_{2}+\lambda_{\mathrm{x} 3} \mathrm{KSI}_{3}+\lambda_{\mathrm{x} 4} \mathrm{KSI}_{4}+\lambda_{\mathrm{x} 5} \mathrm{KSI}_{5}+\lambda_{\mathrm{x} 6} \mathrm{KSI}_{6}+$ \\
& $\beta \mathrm{y}_{2} \mathrm{ETA}_{2}+\varepsilon_{1}$ \\
Water Needs $\left(\mathrm{ETA}_{2}\right.$ or $\left.\mathrm{Y}_{2}\right)$ & $\mathrm{ETA}_{2}=\lambda_{\mathrm{x} 1} \mathrm{KSI}_{1}+\lambda_{\mathrm{x} 2} \mathrm{KSI}_{2}+\lambda_{\mathrm{x} 3} \mathrm{KSI}_{3}+\lambda_{\mathrm{x} 4} \mathrm{KSI}_{4}+\lambda_{\mathrm{x} 5} \mathrm{KSI}_{5}+\lambda_{\mathrm{x} 6} \mathrm{KSI}_{6}+$ \\
& $\beta \mathrm{y}_{1} \mathrm{ETA}_{1}+\varepsilon_{2}$ \\
\hline
\end{tabular}

Statistical t test: To test the significance of the individual parameters (statistical $t$ test), it has been done by comparing the statistics with the critical point value according to the table. If the statistic value of $t>$

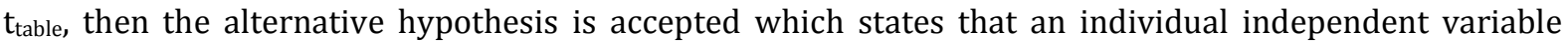
does affect the dependent variable.

\section{Findings and Discussion}

Analysis Factor in the Structural Equetion Model: Prior to the data analysis, a test is conducted to assess the validity of the data. It includes the detection of the presence of non-response bias, the possibility of the violation of the assumptions that must fulfill the method of maximum likelihood estimation with structural equation models. There are two types of tests in this phase and they are; the Confirmatory Factor Analysis (CFA) which is the measurement model and the structural equation model (SEM). The CFA measurement model is directed to investigate the unidimensionality from indicators that describe a latent variable. The value of the outer loadings uses the convergent validity to test the unidimensionality of each construct. According to Chin (1998), the values of the indicator loading factor greater than 0.5 imply that it is valid. In addition to the above criteria, the test should also be tested statistically which can be seen from the result for the outer loadings. The value is significant where the value of t-statistics is greater than 1.96, or vice versa. Upon conducting a factor test on several indicators, the composite reliability test is then performed to see the reliability of a construct or the latent variables as shown in the following table.

Tabel 3: Composite Reliability

\begin{tabular}{ll}
\hline & Composite Reliability \\
\hline Biophysical Aspect & 0.981 \\
Economic Aspect & 0.825 \\
Location Aspect & 0.962 \\
Socio-cultural Aspect & 0.973 \\
Institution Aspect & 0.840 \\
Enviromental Aspect & 0.971 \\
Clean Water Supply Aspect & 0.880 \\
Clean Water Needs Aspect & 0.937 \\
\hline
\end{tabular}

Source : Data Analysis Output, 2014

As depicted in Table 3, the composite reliability values of each construct are greater than 0.7 which has 0.981 on the biophysical aspect, economic aspect of 0.825 , location aspect of 0.962 , socio-cultural aspect of 0.973 , institutional aspect of 0.840 , environmental aspect of 0.971 , the water supply aspect of 0.880 and the clean water needs aspect of 0.937 . It is concluded that the latent in each of the 8 variables is reliable.

Analysis of Determinant Coefficient $\left(\mathbf{R}^{2}\right)$ : The determinant of coefficient is a measure of the representation of the dependent variable by the independent variables or the extent to which the independent variables are able to explain the dependent variable. The coefficient is between 0 to 1 or $0 \leq$ $\mathrm{R}^{2} \leq 1$. When the value of $\mathrm{R}^{2}$ is small, this means that the ability of the independent variables in explaining the variation in the dependent variable is very limited. The value close to 1 means that the independent variables provide almost all the information needed to predict the variation in the dependent variable (Ghozali, 2005). The following table is the results of determinant coefficient $\left(\mathrm{R}^{2}\right)$ of data that have been processed by the Smart PLS software: 


\begin{tabular}{ll}
\hline & R-square \\
\hline Biophysical Aspect & - \\
Economic Aspect & - \\
Location Aspect & - \\
Socio-cultural Aspect & - \\
Institution Aspect & - \\
Enviromental Aspect & - \\
Clean Water Supply Aspect & 0.960 \\
Clean Water Needs Aspect & 0.968 \\
\hline
\end{tabular}

Source : Data Analysis Output, 2014

As illustrated in Table 4, the value of determinant coefficient $\left(\mathrm{R}^{2}\right)$ is 0.960 . This indicates that $96 . \%$ of the water supply in Medan city can be explained by the variation of the variables of the biophysical aspect, economic, location, socio-cultural, institutional and environmental aspects. Meanwhile, the rest of $4 \%$ is explained by other variables. Furthermore, the value of the determinant coefficient for the needs of clean water variable is 0.968 . This indicates that $96.80 \%$ of the clean water in Medan city can be explained by the variation of the variables of biophysical, economic, location, socio-cultural, institutional and environmental aspects, whereas the rest of $3.20 \%$ is explained by other variables.

Analysis of Structural Model: The result for inner weights has the aim to look at the significance of the influence of exogenous and endogenous variables. The values are significant when the t-statistic is greater than 1.96 or otherwise.

Table 5: Results for Inner Weights

\begin{tabular}{llll}
\hline & Original sample estimate & Standard Deviation & t-statistic \\
\hline Biophysical of Water Supply & 0.500 & 0.093 & 5.376 \\
Economic of Water Supply & 0.367 & 0.089 & 4.607 \\
Location of Water Supply & 0.036 & 0.138 & 0.264 \\
Socio-Cultural of Water Supply & 0.499 & 0.120 & 4.163 \\
Institution of Water Supply & 0.135 & 0.044 & 3.099 \\
Enviromental of Water Supply & 0.068 & 0.139 & 7.700 \\
Biophysical of Water Needs & 0.554 & 0.066 & 8.448 \\
Economic of Water Needs & 0.227 & 0.094 & 2.412 \\
Location of Water Needs & 0.262 & 0.087 & 3.013 \\
Socio-Cultural of Water Needs & 0.483 & 0.079 & 6.093 \\
Institution of Water Needs & 0.025 & 0.026 & 0.994 \\
Enviromental of Water Needs & 0.476 & 0.119 & 2.995 \\
Water Supply of Water Needs & 0,324 & 0,046 & 6.995 \\
Water Needs of Water Supply & 0,466 & 0,130 & 3.582 \\
\hline
\end{tabular}

Source : Data Analysis Output, 2014

Furthermore, processing the data using structural equation models with Smart PLS software is displayed in the structural analysis as depicted in Figure 4. 


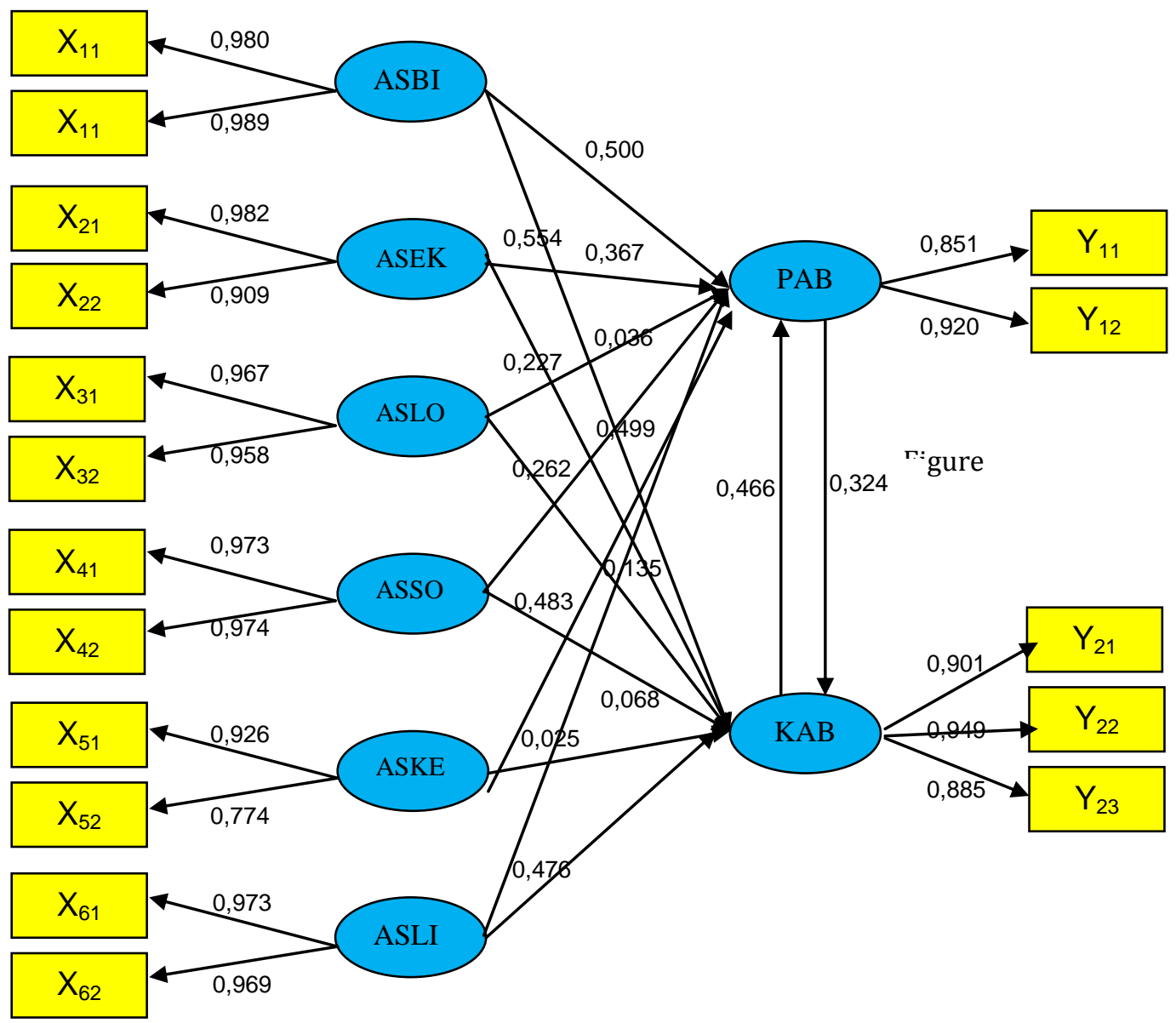

\section{Hypothesis Test 1, The effect of Regional Development on Clean Water Supply.}

a) Biophysical aspect affects positively the clean water supply in Medan city: Based on statistical tests, it is known that the latent variable of the biophysical aspect on water supply or the $\mathrm{X}_{1}$ to $\mathrm{Y}_{1}$ does have a significant effect due to the value of t-statistic $>1.96$ or $5.376>1.96$ (Table 5). Since the value of $t$ statistic $>1.96$, then the hypothesis is accepted where the variable of the biophysical aspect has a positive and significant effect on the water supply. This is due to the increased population and population density, and thus the water needs by the public will be increased as well. This result is consistent with the study by Raharjo (2002) and Sari (2001), which states that the regional development in an area will cause the water needs to continuously increase in line with the population growth. The fulfillment of food requirements and people's activities are always closely related to the needs for water and its supply. The domestic needs are determined by the presence of domestic consumers, which is derived from population data, habits and patterns of living supported by the socio-economic development that highlights the increasing tendency to be needing clean water (Purwohandoko, 2009). Taty and Judo (2007) stated that the amount of clean water requirements is based on the needs of the water with population growth. This finding is aligned with the research conducted by Indra et al. (2011).

b) Economic aspect affects positively the clean water supply in Medan city: It is found that the latent variable of the economic aspect on water supply or $\mathrm{X}_{2}$ to $\mathrm{Y}_{1}$ has a significant effect due to the value of $\mathrm{t}$ statistic $>1.96$ or $4.607>1.96$. Since the value of $t$-statistic $>1.96$, then the hypothesis is accepted in which the economic aspect variable positively and significantly affects the water supply. This is due to the increase in the per capita income and gross regional domestic product that will increase the supply of clean water for the community. This result is consistent with a study by Sari (2001) which states that the regional development will lead to an increase in the per capita income and economic growth, thus the need for water and water supply will increase. Meanwhile, Idris (2007) has stated that the economic 
aspect aims to establish the economic institutions of a healthy clean water sector to improve the role and impact of the clean water sector to the regional economy. The strategy is expressed in two ways namely; (i) an increase in financial and operational performance; and (ii) an increase in the share and impact of the clean water sector in the regional economy.

c) Location aspect affects positively the clean water supply in Medan city: It is found that the latent variable of the location aspect on water supply or $\mathrm{X}_{3}$ to $\mathrm{Y}_{1}$ is not significant because the t-statistic values $<1.96$ or $0.264<1.96$. Since the value of t-statistic $<1.96$, then the hypothesis is rejected. This is due to the great distance of the water supply, where the larger the cost of water released for distribution to the public, the higher loss of water source it will be. These are aligned with the findings by Mays (2001) who states that the activities of the clean water provision through springs absorption is crucial for water providers. This is also consistent with the results by Yunius (2005) stating that an increase in the capacity of services is performed by the optimization of production and distribution system, reduction of water loss, the construction of Water Supply Installation, human resource development, rehabilitation and revitalization of systems. Thus, it is deemed necessary to develop services with localized distribution pipeline expansion on potential sites.

d) Socio-cultural aspect affects positively the clean water supply in Medan city: It is found that the latent variable of socio-cultural aspect on the water supply or X4 Y1 has a significant effect due to the value of t-statistic $>1.96$ or $4.163>1.96$. Since the value of t-statistic $>1.96$, then the hypothesis is accepted. This is due to the increasing number of colleges and medical personnel, that will increase the supply of clean water for colleges and medical institutions. This result is consistent with the findings by Hardini (2003) whereby the basic physical conditions and infrastructure affect the regional development, thus will increase the supply of clean water. Conversely, a poor drainage system can result in a decline in environmental quality and public health. High leakage rate taps and low production capacity of clean water are also problems in a region affecting clean water services, and further causing the water supply to decrease. Therefore, it needs sufficient clean water infrastructures and facilities in improving the provision of adequate clean water in the future.

e) Institutional aspect affects positively towards the clean water supply in Medan city: Based on the statistical tests, it is found that the latent variable of the institutional aspect on water supply or X5 to Y1 has a significant effectdue to the value of t-statistic $>1.96$ or 3.099> 1.96. Since the value of t-statistic> 1.96 , then the hypothesis is accepted. This is due to the increasing number of the industry and trade that will increase the amount of water supply for the industrial use of small, medium and large industries. This result is aligned with a study by Hardini (2003) where it states that the basic physical conditions and infrastructure affect the regional development, thus will increase the supply of clean water.

f) Enviromental aspect affects positively towards the clean water supply in Medan city: Based on the statistical tests, it is found that the latent variableof the environmental aspect on the water supply or X6 to $\mathrm{Y} 1$ has a significant effect due to the value of $\mathrm{t}$-statistic $>1.96$ or $7.700>1.96$. Since the value of $\mathrm{t}$ statistic $>1.96$, then the hypothesis is accepted. This is due to the increased budget for waste treatment and garbage cleanliness that will enhance the environment and increase the availability of clean water. This findings are consistent with the results of the study by Mungkasa (2006), where it states that the increased water investment will result in a better supply of clean water as well as increase in economic growth; yet, it has no effect on the reduction of the society's income's inequality level.

\section{Hypothesis Test 2, The Effect of Regional Development towards the Needs of Clean Water.}

a) Biophysical aspect affects positively the needs of clean water in Medan city: Based on the statistical tests, it is found that the latent variable of the biophysical aspect on the need for clean water or X1 to Y2 has a significant effect due to the value of $t$-statistic $>1.96$ or $8.448>1.96$. Since the value of $t$-statistic $>1.96$, then the hypothesis is accepted. This is due to the increasing population and population density in a region that will increase water needs by the public, increase the needs of water for use as drinking water etc. This result is consistent with the findings by Raharjo (2002) where the number of residents, amount and type of facilities in the city, income level, education level of the population, quality of service, the price of water, soil and climatic can all affect the needs for clean water. 
b) Economic aspect affects positively the needs of clean water in Medan city: Based on the statistical tests, itis found that the latent variable ofthe economic aspect on the needs of clean water or X2 to Y2 has a significant effect due to the value of t-statistic $>1.96$ or $2.412>1.96$. Since the value of t-statistic $>1.96$, then the hypothesis is accepted. This is due to the increase in the per capita income and gross regional domestic product that will increase the needsfor clean water for the community. This result is consistent with the findings by Irawan (2002) stating that water consumption is significantly affected by the level of income and family size. If the level of income and number of family members increases, then the water consumption will also increase.

c) Location aspect affects positively the needs for clean water in Medan city: Based on the statistical tests, it is found that the latent variable of the location aspect on the needs for clean water or X3 Y2 has a significant effect due to the value of t-statistic $>1.96$ or $3.013>1.96$. Since the value of t-statistic $>1.96$, then the hypothesis is accepted. This is due to the increasing number of public transport and the road length that will increase the needs for clean water to be transported. This result is consistent with the findings by Raharjo (2002) stating that the number of residents, amount and type of facilities in the city, income level, education level of the population, quality of service, the price of water, soil and climate have a partial influence and are simultaneously significant on the needs for clean water.

d) Socio-cultural affects positively the needs for clean water in Medan city: Based on the statistical tests, it is found that the latent variable of the socio-cultural aspect on the need for clean water or X4 Y2 has a significant effect due to the value of t-statistic $>1.96$ or $6.093>1.96$. Since the value of t-statistic $>1.96$, then the hypothesis is accepted. This is due to the increasing number of colleges and medical personnel that will increase the needs to promote better cleanliness in colleges and medical institutions. This result is aligned with the findings by Raharjo (2002) who states that the number of residents, amount and type of city facilities, income level, education level of the population, quality of service, the price of water, soil and climate influence are partially and simultaneously significant on the needs to have clean water.

e) Institutional aspect affects positively the needs for clean water in Medan city: Based on the statistical tests, it is found that the latent variable of the institutional aspect on the needs of clean water or X5 Y2 affects insignificantly due to the value of t-statistic $>1.96$ or $0.994<1.96$. Since the value of $t$ statistic $<1.96$, then the hypothesis is rejected. This is due to the increasing number of industry and trade that will increase the amount of clean water for industrial use. This result is aligned with a study by Hardini (2003) whereby the basic physical conditions and infrastructure do affect the regional development, thus the needs for clean water will increase.

f) Environmental aspect affects positively the needs for clean water in Medan city: Based on the statistical tests, it is found that the latent variable of the environmental aspect on the needs for clean water or X6 to Y2 has a significant effect due to the value of t-statistic> 1.96 or $3.995>1.96$. Since the value of $t-$ statistic $>1.96$, then the hypothesis is accepted. This is due to the increased budget for waste treatment and garbage cleanliness that will increase the needs for clean water. This result is aligned with a study by Mungkasa (2006) that the increased investment of drinking water will result in increased economic growth but will leave no effect on reducing the income gap.

\section{Hypothesis Test 3, The Effect of the Supply of Clean Water towards the Needs for Clean Water}

Based on the statistical tests, it is found that the latent variable of water supply on the needs for clean water or Y1 to Y2 has a significant effect due to the value of t-statistic $>1.96$ or $6.995>1.96$. Since the value of t-statistic $>1.96$, then the hypothesis is accepted. The provision of water is a production that produces water to meet the needs of customers, not the overall population in the city. The increased production of the amount forclean water also coincides with the increase in the population and industries that require clean water. The needs for clean waterarerequired for the residents and industry, which thus far has been disappointing. Thus, it is important to produce an innovative water treatment that exceeds the standards required due to the needs for clean water as a basic requirement.This result is aligned with the findings by Hardini (2003) that the basic physical conditions and infrastructure affect the regional development, thus will increase the supply of clean water. 


\section{Hypothesis Test 4, The Effect the Needs of Clean Water towards the Supply of Clean Water}

Based on the statistical tests, it is found that the latent variable of the needs for clean water on water supply or Y2 to Y1 has a significant effect due to the value of $t$-statistic $>1.96$ or $3.582>1.96$. Since the value of $\mathrm{t}$-statistic $>1.96$, then the hypothesis is accepted. The growing need for clean water for residents and industries in Medan should be coupled with the provision of clean water. The results above illustrate that there is a positive relationship or a two-way relationship between water supply and water needs. Therefore, to prevent a reduction in the supply of water or water deficit ahead, it is necessary to have a good water management. This is due to the increasing population, industrial and other activities that will increase the needs for clean water. This result is consistent with a study by Setyandito et al. (2006) which states that the need for water is greater than the existing availability of water for each district/town.

\section{Conclusion}

Based on the above results it can be concluded as follows:

- The biophysical aspect assessed by the population and its density affect positively and significantly the supply of clean water and the needs for clean water.

- The economic aspect assessed by the per capita income and gross regional domestic product affect positively and significantly the supply of clean water and the needs for clean water.

- The location aspect assessed by the number of public transport and path length affect positively and significantly the supply of clean water and the needs for clean water.

- The socio-cultural aspect assessed by the number of colleges and medical personnels affect positively and significantly the supply of clean water and the needs for clean water.

- The institutional aspect assessed by the number of industries and trades affect positively and significantly the supply of clean water and the needs for clean water.

- The environmental aspect assessed by the budget of waste treatment and garbage cleanliness affect positively and significantly the supply of clean water and the needs for clean water.

- The biophysical aspect is the greatest influence and thus, it can significantly affect the supply and needs of clean water.

- The aspect of the supply of clean water has a positive effect on the needs for clean water in Medan city.

- The needs for clean water has a positive effect on the water supply in Medan city.

Meanwhile, to improve the water management in Medan city, based on the discussion of the results of the study, some suggestions can be presented as follows:

- For the researchers; they are recommended to conduct further research on the strategic development of water management in various production centers such as in the province of North Sumatra.

- For the Government; it must pay attention to the great potential of future water needs policy support in the form of access to capital assistance, ease in handling permits more efficiently, and supports in cooperation with other parties, both within and outside the Medan city.

- For the local government in Medan city; it needs to create a conducive investment climate so as to promote economic growth or GDP that can ultimately improve water supply and needs.

\section{Reference}

Budiharsono, S. (2005). Teknik Analisis Pembangunan Wilayah Pesisir dan Lautan (Technical Analysis of Development in Marine and Coastal Regions). Cetakan kedua. Jakarta: Pradnya Paramita.

Chin, W. W. (1998). The Partial Least Squares Approach for Structural Equation Modeling. In Marcoulides, G.A. (Ed), Modern Method for Business Resaearch, Mahwah. NJ. Erlbaum Associates, 295 - 358.

Douglass, M. (2001). Urban and Regional Policy after the Era of Naïve Globalism'dalam A. Kumasa dan T. McGee (ed), New Regional Development Paradigms: Globalization and the New Regional Development, Greenwood Press, Westport, Connecticut, 33-56.

Ernan, R. (2011). Perencanaan dan Pengembangan Wilayah (The Regional Planning and Development). Yayasan Pustaka Obor Indonesia Jakarta.

Friedman, J. \& Allonso, L. (1964). Regional Economic Development and Planing. London: MT Press.

Ghozali, I. (2005). Aplikasi Analisis Multivariate Dengan Program SPSS (Application Analysis of Multivariate with SPSS Program). Semarang: Badan Penerbit UNDIP.

Hanafiah, T. (1982). Pendekatan Wilayah Terhadap Masalah Pembangunan Pedesaan (An Approach of 
Problems in Regional Development). Fakultas Pertanian IPB. Bogor.

Hardini, A. (2003). Studi Pelayanan Air Bersih di Kecamatan Pademangan, Jakarta Utara (A study on Clean Water Services in Pademangan Sub-region, North Jakarta.

Idris, A. (2007). Kinerja Perusahaan Daerah Air minum Terhadap Kualitas Air di Provinsi Kalimantan Timur. Jurnal Eksekutif, 4(2). Universitas Mulawarman, Kota Samarinda, Kalimantan Timur.

Indra, K. S., Lily, M. L. \& Dwi, P. (2011). Analisis Kesediaan dan Kebutuhan Air pada DAS Sampean (An Analysis of Availability and Needs of Water in Sampean).

Irawan, B. (2002). Arahan Pengembangan Sistem Pelayanan Air Bersih Kota Palembang (A Direction of Clean Water Services System in Palembang city).

Mays, L. W. (2001). Water Resources Engineering First Edition. Arizona State University. US: John Wiley \& Sons Inc.

Medan in Figures. (2011). Badan Pusat Statistik. Medan: Badan Pusat Statistik.

Mungkasa, O. M. (2006). Dampak Investasi Air Minum terhadap Pertumbuhan Ekonomi dan Distribusi Pendapatan di DKI Jakarta (The Impact of Drinking Water Investment towards the Economic Growth and Income Distribution in Jakarta).

Myrdal, G. (1960). Economic Theory and Underdeveloped Regions. London: Gerald Duckworth \& Co.

Nace, R. L. (1976). Hydrology in Hanbook of Water Resources and Pollution Control. Ed. By HW Gehm. New York: Van Nostrand Reinhold Co.

Purwohandoko, I. (2009). Pengaruh Tangible Resource Perusahaan Terhadap Kinerja Perusahaan Air Minum Dalam Kemasan di Wilayah Sidoarjo Surabaya dan Pasuruan. Jurnal Manajemen dan Kewirausahaan, 11(2). Fakultas Ekonomi Universitas Negeri Surabaya.

Raharjo. (2002). Faktor-faktor yang mempengaruhi tingkat konsumsi air bersih di kota rembang (Factors affecting the Clean Water Consumption Level in Rembang city).

Sari, K. (2001). Identifikasi Pola Konsumsi Air Bersih Rumah Tangga (The Identification of Household Consumption Model of Clean Water). Dissertation in Planalogy Engineering. Institut Teknologi Bandung.

Setiono, D. N. S. (2011). Ekonomi Pengembangan Wilayah teori dan analisis (Theory and Analysis on Economics of Regional Development). Fakultas Ekonomi UI. Jakarta

Setyandito, O., Wijayanti, Y. \& Setyawan, A. (2006). Rencana Tindak Penyediaan Air Bersih di Provinsi Nusa Tenggara Barat (The Action Plan of Clean Water Provision in Nusa Tenggara Barat Province). Jurnal Teknik Sipil, Fakultas Teknik Universitas Mataram Nusa Tenggara Barat, 6(2).

Taty, H. \& Judo, S. (2007). Alternatif teknologi pengelolaan air untuk memenuhi kebutuhan air bersih di daerah pemukiman nelayan (An Alternative of Water Management Technology in Fulfillment of Clean Water in Fishermen Villages).

Yunius, M. (2005). Peningkatan Kapasitas Pelayanan Air Bersih PDAM Tirta Mayang Kota Jambi. 